\title{
Child maltreatment: knowledge, attitudes and reporting behaviour of physicians in teaching hospitals, Egypt
}

Nourhan Saeed, ${ }^{1}$ Eman Anwar Sultan, ${ }^{2}$ Naglaa Salama, ${ }^{1}$ Mohammed Galal ${ }^{3}$ and Maha Ghanem ${ }^{1}$

${ }^{1}$ Department of Forensic Medicine and Clinical Toxicology, Faculty of Medicine, University of Alexandria, Alexandria, Egypt. ${ }^{2}$ Department of Community Medicine, Faculty of Medicine, University of Alexandria, Alexandria, Egypt. ${ }^{3}$ Department of Ophthalmology, Faculty of Medicine, University of Alexandria, Alexandria, Egypt. (Correspondence to: Nourhan Saeed: nourhanaboshabana@gmail.com).

\begin{abstract}
Background: Lack of diagnosis and reporting of child maltreatment are important problems worldwide.

Aims: This study aimed to assess the knowledge, attitude and practice of physicians in Alexandria University teaching hospitals about the diagnosis and reporting of child maltreatment cases.

Methods: A descriptive cross-sectional study was conducted at three hospitals. All physicians working regularly in emergency units were invited to complete a self-administered questionnaire. Data collected included sociodemographic characteristics, knowledge of and formal training on child maltreatment, attitude to dealing with child maltreatment, and experience of child maltreatment cases and reporting behaviour.

Results: A total of 90 physicians were included in the study. Only $11 \%$ correctly identified all the signs of child maltreatment and $29 \%$ correctly answered all questions on the social indicators of maltreatment. Only $41 \%$ of the participants had a good knowledge score $(\geq 75 \%)$ on child maltreatment. Longer work experience $(P=0.019)$ and older age $(P=0.039)$ were associated with better knowledge. Of 249 suspected cases of child maltreatment that the physicians reported they had experienced, only $36 \%$ were reported. Formal training on child maltreatment $(P<0.001)$ and older age $(P=0.006)$ were associated with physicians' reporting behaviour. Over half $(56 \%)$ of the participants thought their workplaces did not provide them with procedures to follow if they suspected child maltreatment.

Conclusion: Physicians' knowledge of the signs and social indicators of child maltreatment was unsatisfactory. Clinical training and education are needed to improve their ability to diagnosis and report cases of child maltreatment.

Keywords: child abuse, physicians, knowledge, university hospitals, Egypt

Citation: Saeed N; Sultan EA; Salama N; Galal M; Ghanem M. Child maltreatment: knowledge, attitudes and reporting behaviour of physicians in teaching hospitals, Alexandria, Egypt. East Mediterr Health J. 2021;27(3):250-259. https://doi.org/10.26719/emhj.20.126

Received:03/12/19; accepted: 17/03/20

Copyright $@$ C World Health Organization (WHO) 2021. Open Access. Some rights reserved. This work is available under the CC BY-NC-SA 3.o IGO license (https://creativecommons.org/licenses/by-nc-sa/3.o/igo).
\end{abstract}

\section{Introduction}

Child maltreatment is a problems in all countries, possibly because of failure in committing to child rights (1). The World Health Organization (WHO) estimated in 2016, that 1 in 2 children aged 2-17 years had suffered violence in the past year. Boys and girls are at equal risk of physical and emotional abuse and neglect, and girls are at greater risk of sexual abuse (2).

Lack of diagnosis and reporting of child maltreatment were considered the main problems in stopping the maltreatment in up to $75 \%$ of cases (3). Reporting all cases of child maltreatment is vital in order to prevent further exposure, protect children and enhance coordination between legal, medical and social services. However, physicians need preparation for the ethical and legal challenges in cases of child maltreatment. This is considered necessary because evidence suggests that, on their own, physicians are not able to deal with these challenges when confronted with them (4-6).

Few studies about child maltreatment in Egypt are available. One study estimated that $91 \%$ of children in Egypt are exposed to child abuse with varying degrees of severity (7). In Egypt, law No. 126 ensures a child's right to be protected from all forms of violence (8). However, no law states the mandatory reporting of child maltreatment and penalties of non-reporting. In this study we, aimed to assess the knowledge, attitude and opinion of physicians in Alexandria University teaching hospitals about the diagnosis and reporting of child maltreatment as an important first step to developing interventions and setting laws and legislations to protect children from maltreatment.

\section{Methods}

\section{Setting and sample}

We conducted a descriptive cross-sectional study from July to December 2018 at three hospitals affiliated to Alexandria University: Main University Hospital, El-Shatby hospital and El-Hadara hospital. Our sample was all physicians (residents, teaching assistants and assistant lecturers) working in the emergency units of these hospitals on a regular basis who had frequent contact with child maltreatment cases and were willing to participate in the study. 


\section{Data collection}

We used a structured self-administered questionnaire for data collection adapted from other questionnaires (9-11). The questionnaire was in English. We tested the validity and reliability of the questionnaire before use. First, we asked three Egyptian experts in the field of medical education and research at the Faculty of Medicine to assess the degree to which items in the questionnaires were relevant and could correctly measure the knowledge and attitudes of participants regarding child maltreatment. As a result of their feedback, we modified questions on the causes of underreporting and not taking action if child maltreatment was suspected to include the main possible causes relevant to the Egyptian culture.

We then pretested the questionnaire on 14 physicians who we excluded from the later study sample. They completed the questionnaire twice, 3 weeks apart. We assessed internal consistency and reliability using the Cronbach alpha and the test-retest reliability using intraclass correlation coefficient. The results showed adequate internal consistency and reliability: Cronbach alpha $=0.82$ and the intraclass correlation coefficient $=0.94$ ). The pilot study also indicated some modifications were needed to the structure of the questionnaire (e.g. using simple, familiar words and clarifying some sentences).

The questionnaire had five main sections:

- Sociodemographic characteristics of the physicians (age, sex, years of experience and highest scientific degree) and formal child maltreatment training.

- Knowledge of physicians about child maltreatment, e.g. knowledge of signs and symptoms of child maltreatment, different forms of child maltreatment and to which legal authority child maltreatment cases should be reported.

- Attitudes of physicians to child maltreatment using a five-point Likert scale and their opinions on the main causes of underreporting of child maltreatment cases.

- Experience of physicians of cases of child maltreatment, their reporting behaviour with suspected cases of child maltreatment and barriers to reporting suspected cases.

- Physicians' satisfaction with their knowledge of child maltreatment and procedures of dealing with child maltreatment, and their desire to improve their knowledge and how they could do this.

The physicians completed the questionnaire with a researcher available for any questions. As the researcher dealt with the respondents personally, there was no risk of the same physician completing the questionnaire more than once. The questionnaire took on average about 15-20 minutes to complete.

\section{Data analysis}

We used SPSS, version 20.0 for data entry and analysis $(12,13)$. For testing associations between qualitative vari- ables, we used the chi-squared, Fisher exact and Monte Carlo tests. For normally distributed quantitative variables, we used a two-sample t-test to compare between two groups and ANOVA to compare between more than two groups. We considered $P \leq 0.05$ statistically significant.

For each knowledge question, we assigned a score of 1 for a correct answer and o for an incorrect answer. The maximum total score was 21 . We summed the scores and calculated the total percentage score. We rated the total percentage scores as follows: $<50 \%=$ poor knowledge, $50 \%$ to $<75 \%$ = fair knowledge and $\geq 75 \%$ = good knowledge.

\section{Ethical considerations}

The Institutional Review Board of the Faculty of Medicine, Alexandria University approved the study (IRB 0121026, FWA 00018699) on 16 November 2017. Verbal consent was collected from participants and data was collected anonymously to ensure confidentiality.

\section{Results}

The questionnaire was distributed by the researchers to all the target physicians at the emergency departments of the three studied hospitals. The physicians were asked to self-complete the questionnaire with a researcher available for any questions. Of the 120 physicians approached, 102 agreed to participate, response rate of $85 \%$. In addition, 12 physicians did not answer some of the questions and we excluded them. Therefore, 90 respondents were included in the analysis.

The age of physicians ranged from 25 to 33 years with a mean of 28.33 (SD 1.9) years. Just over half $(46(51 \%))$ of the physicians were men. Half of the physicians ( 45 $(50 \%))$ had $6-10$ years of work experience, $38(42 \%)$ had 5 years or fewer, and only $7(8 \%)$ had more than 10 years of experience. Moreover, 37 (41\%) of the sample were specialized in paediatrics, $18(20 \%)$ were orthopaedic surgeons, 18 (20\%) were forensic medicine and toxicology specialists and $17(19 \%)$ were emergency room physicians. Most of the physicians (62 (69\%)) had a bachelor's degree and $28(31 \%)$ had a master's degree.

Most of physicians $(83(92 \%))$ said that they had never received any formal training specific to child maltreatment while only $7(8 \%)$ indicated that they had.

Knowledge of the physicians about child maltreatment is given in Table 1. Only 10 (11\%) of the physicians correctly identified all the signs of child maltreatment. Burn marks was the most frequently identified sign (86 (96\%)) followed by broken teeth without reasonable cause (80 $(89 \%))$. Eleven (12\%) physicians did not know the signs of child maltreatment.

About a third of the physicians $(29(32 \%))$ responded correctly to all the questions on the action that should be taken when they suspected a case of child maltreatment. Reporting the case to a legal authority was the most common chosen action (79 (88\%)). Nevertheless, (5 (6\%)) indicated that the physicians should not take any action. More than half of the physicians (52 (58\%)) thought the 


\begin{tabular}{|c|c|c|}
\hline Knowledge of physical indications of child maltreatment & $\begin{array}{l}\text { No. (\%) } \\
\text { Yes }\end{array}$ & $\begin{array}{l}\text { No. (\%) } \\
\text { No }\end{array}$ \\
\hline \multicolumn{3}{|l|}{ Sign of child maltreatment } \\
\hline Bruises over bony prominences & $70(78)$ & $20(22)$ \\
\hline Broken teeth, without reasonable cause ${ }^{\mathrm{a}}$ & $80(89)$ & $10(11)$ \\
\hline Burn marks ${ }^{\mathrm{a}}$ & $86(96)$ & $4(4)$ \\
\hline Dental caries & $23(26)$ & $67(74)$ \\
\hline Head trauma ${ }^{a}$ & $69(77)$ & $21(23)$ \\
\hline Bite marks ${ }^{\mathrm{a}}$ & $71(79)$ & $19(21)$ \\
\hline Careless parents ${ }^{\mathrm{a}}$ & $69(77)$ & $21(23)$ \\
\hline Shy personality & $37(41)$ & $53(59)$ \\
\hline Has attempted suicide ${ }^{a}$ & $48(53)$ & $42(47)$ \\
\hline Abuses alcohol or other drugs ${ }^{a}$ & $46(51)$ & $44(49)$ \\
\hline I don't know & $11(12)$ & $79(88)$ \\
\hline All correct answers (7 signs) & $10(11)$ & $80(89)$ \\
\hline Knowledge of social indicators of child maltreatment & True & False \\
\hline $\begin{array}{l}\text { Children who have been exposed to child maltreatment will usually tell someone soon after the } \\
\text { abuse }\end{array}$ & $24(27)$ & $66^{a}(73)$ \\
\hline $\begin{array}{l}\text { Child maltreatment is primarily associated with the stresses of poverty and rarely occurs in middle- } \\
\text { or high-income families }\end{array}$ & $44(49)$ & $46^{\mathrm{a}}(51)$ \\
\hline The abuser in most cases is someone the child knows well from his/her surrounding environment & $73^{a}(81)$ & $17(19)$ \\
\hline $\begin{array}{l}\text { The best way to deal with suspected cases of child maltreatment is to confront the parents and } \\
\text { accuse them directly of the abuse }\end{array}$ & $26(29)$ & $64^{\mathrm{a}}(71)$ \\
\hline \multirow[t]{2}{*}{ All correct answers (4 items) } & Yes & No \\
\hline & $26(29)$ & $64(71)$ \\
\hline \multicolumn{3}{|l|}{ First action a physician should take if he/she suspects child maltreatment } \\
\hline Ask the child and parents about the signs/symptoms you noticed ${ }^{a}$ & $71(79)$ & $19(21)$ \\
\hline Document the signs/symptoms and your suspicion on the child's file ${ }^{a}$ & $70(78)$ & $20(22)$ \\
\hline Monitor the case in following visits ${ }^{\mathrm{a}}$ & $56(62)$ & $34(38)$ \\
\hline Report to a legal authority ${ }^{\mathrm{a}}$ & $79(88)$ & $11(12)$ \\
\hline Check the consistency of parents' and/or child's explanation with the clinical findings ${ }^{a}$ & $67(74)$ & $23(26)$ \\
\hline Do nothing & $5(6)$ & $85(94)$ \\
\hline Don't know & $11(12)$ & $79(88)$ \\
\hline All correct answer (5 actions) & $29(32)$ & $61(68)$ \\
\hline \multicolumn{3}{|l|}{ Circumstances in which physicians should report cases of child maltreatment to an authority } \\
\hline All circumstances even if child maltreatment is only suspected ${ }^{a}$ & $60(67)$ & $30(33)$ \\
\hline In severe cases of child maltreatment & $27(30)$ & $63(70)$ \\
\hline In cases where the physical violence to a child is repetitive & $27(30)$ & $63(70)$ \\
\hline Never & $0(0)$ & $90(100)$ \\
\hline Don't know & $7(8)$ & $83(92)$ \\
\hline The authority to which child maltreatment cases should be reported (select only one answer) & \multicolumn{2}{|c|}{ No. (\%) } \\
\hline Your superior & \multicolumn{2}{|c|}{$11(12)$} \\
\hline Head of your department & \multicolumn{2}{|c|}{$10(11)$} \\
\hline Ministry of Health & \multicolumn{2}{|c|}{$1(1)$} \\
\hline Police $^{\mathrm{a}}$ & \multicolumn{2}{|c|}{$52(58)$} \\
\hline Other, please specify (social worker) & \multicolumn{2}{|c|}{$1(1)$} \\
\hline Don't know & \multicolumn{2}{|c|}{$15(17)$} \\
\hline \multicolumn{3}{|l|}{ Knowledge score } \\
\hline Poor $(<50 \%)$ & \multicolumn{2}{|c|}{$9(10)$} \\
\hline Fair $(50-<75 \%)$ & \multicolumn{2}{|c|}{$44(49)$} \\
\hline Good $(\geq 75 \%)$ & \multicolumn{2}{|c|}{$37(41)$} \\
\hline
\end{tabular}

${ }^{a}$ Correct answer. 
case should be reported to the police and $15(16.7 \%)$ said they did not know which authority a case should be reported to.

Regarding the circumstances in which physicians should report a case of child maltreatment to the authorities, $60(67 \%)$ of the participants correctly identified that it should be reported in all circumstances even if the abuse is only suspected. A minority of physicians $(7(8 \%))$ did not know when to report a case of child maltreatment.

For the social indicators of child maltreatment, $26(29 \%)$ of the physicians correctly answered all four questions. Most $(73(81 \%))$ identified that the abuser in most cases of child maltreatment is someone the child knows well from his/her surrounding environment, $66(73 \%)$ correctly reported that children exposed to maltreatment generally delay telling anybody about the incident, and 64 (71\%) agreed that it was better not to confront the parents and accuse them directly of the abuse. Only $46(51.1 \%)$ of the physicians knew that child maltreatment is not primarily associated with poverty and can occur in any socioeconomic group.
The main sources of knowledge on child maltreatment were undergraduate and postgraduate courses; 50 (56\%) and $20(22 \%)$, respectively. Only $3(3 \%)$ physicians said they had knowledge from clinical experience and $2(2 \%)$ from online sources; 15 (17\%) of the physicians had no sources of information on child maltreatment. None had obtained information through continuing education or special courses on child maltreatment.3

The overall percentage knowledge score ranged from $33.3 \%$ to $100.0 \%$ with a mean (standard deviation) of $69.47 \%(14.52 \%)$ and median of $71.4 \%$. About half the physicians (44 (49\%)) had fair knowledge (score $50-<75 \%$ ) and $37(41 \%)$ had good knowledge (score $\geq 75 \%$ ).

Table 2 shows the association between overall knowledge of child maltreatment, and physicians' demographic characteristics and training of. More than 10 years of experience $(P=0.019)$ and age $\geq 30$ years $(P=0.039)$ were significantly associated with better knowledge of child maltreatment. Level of knowledge was not significantly associated with sex, specialty, qualification and training on child maltreatment.

\begin{tabular}{|c|c|c|c|c|}
\hline \multirow[t]{3}{*}{ Characteristic } & \multicolumn{3}{|c|}{ Overall knowledge } & \multirow{3}{*}{$\begin{array}{l}\text { Test of significance } \\
\text { value (P-value) }\end{array}$} \\
\hline & Poor & Fair & Good & \\
\hline & No. (\%) & No. (\%) & No. (\%) & \\
\hline \multicolumn{5}{|l|}{ Age (years) } \\
\hline$<30$ & $6(9)$ & $38(57)$ & $23(34)$ & \multirow{2}{*}{$6.506^{\mathrm{a}}(0.039)$} \\
\hline$\geq 30$ & $3(13)$ & $6(26)$ & $14(61)$ & \\
\hline \multicolumn{5}{|l|}{ Sex } \\
\hline Male & $4(9)$ & $25(54)$ & $17(37)$ & \multirow{2}{*}{$1.171^{a}(0.586)$} \\
\hline Female & $5(11)$ & $19(43)$ & $20(46)$ & \\
\hline \multicolumn{5}{|l|}{ Years of experience } \\
\hline$\leq 5$ & $5(13)$ & $24(63)$ & $9(24)$ & \multirow{3}{*}{$10.738^{\mathrm{a}}(0.019)$} \\
\hline $6-\leq 10$ & $4(9)$ & $19(42)$ & $22(49)$ & \\
\hline$>10$ & $0(0)$ & $1(14)$ & $6(86)$ & \\
\hline Range & $3.0-8.0$ & $3.0-10.0$ & $4.0-12.0$ & \multirow{2}{*}{$0.849^{\mathrm{b}}(0.431)$} \\
\hline Mean (SD) & $6.11(1.62)$ & $5.93(1.62)$ & $6.49(2.27)$ & \\
\hline \multicolumn{5}{|l|}{ Specialty } \\
\hline Pediatrics & $6(16)$ & $16(43)$ & $15(40)$ & \multirow{4}{*}{$6.465^{\mathrm{a}}(0.356)$} \\
\hline Orthopedics & $1(6)$ & $8(44)$ & $9(50)$ & \\
\hline Emergency room & $2(12)$ & $11(65)$ & $4(23)$ & \\
\hline Forensic and toxicology & $\mathrm{o}(0)$ & $9(50)$ & $9(50)$ & \\
\hline \multicolumn{5}{|l|}{ Highest/last scientific degree } \\
\hline Bachelor's degree & $5(8)$ & $34(55)$ & $23(37)$ & \multirow{2}{*}{$2.971^{\mathrm{a}}(0.226)$} \\
\hline Master's degree & $4(14)$ & $10(36)$ & $14(50)$ & \\
\hline \multicolumn{5}{|c|}{ Received formal training on child maltreatment } \\
\hline Yes & $1(14)$ & $2(29)$ & $4(57)$ & \multirow{2}{*}{$1.675^{\mathrm{a}}(0.406)$} \\
\hline No & $8(10)$ & $42(51)$ & $33(40)$ & \\
\hline
\end{tabular}

$\mathrm{SD}=$ standard deviation

${ }^{a}$ Chi squared test.

${ }^{b} \mathrm{~F}$ for ANOVA test.

$P \leq 0.05$ was considered statistically significant 


\begin{tabular}{|c|c|c|c|c|c|}
\hline \multirow[t]{2}{*}{ Statements on child maltreatment } & $\begin{array}{l}\text { Strongly } \\
\text { disagree }\end{array}$ & Disagree & Neutral & Agree & $\begin{array}{l}\text { Strongly } \\
\text { agree }\end{array}$ \\
\hline & No. (\%) & No. (\%) & No. (\%) & No. (\%) & No. (\%) \\
\hline Detecting and reporting child maltreatment is important & $0(0)$ & $0(0)$ & $2(2)$ & $13(14)$ & $75(83)$ \\
\hline $\begin{array}{l}\text { Physicians have an important role in detecting and reporting } \\
\text { cases of child maltreatment }\end{array}$ & $\mathrm{o}(0)$ & $\mathrm{o}(\mathrm{o})$ & $1(1)$ & $24(27)$ & $65(72)$ \\
\hline As a physician, you are able to detect child maltreatment cases & $\mathrm{o}(0)$ & $\mathrm{o}(0)$ & $11(12)$ & $45(50)$ & $34(38)$ \\
\hline $\begin{array}{l}\text { Documenting the signs/symptoms of child maltreatment in the } \\
\text { patient file is important }\end{array}$ & $\mathrm{o}(0)$ & $1(1)$ & $7(8)$ & $21(23)$ & $61(68)$ \\
\hline Asking the child about injuries he/she had is important & $\mathrm{o}(0)$ & $1(1)$ & $5(6)$ & $28(31)$ & $56(62)$ \\
\hline $\begin{array}{l}\text { Reporting child maltreatment cases to a legal authority is } \\
\text { important }\end{array}$ & $\mathrm{o}(0)$ & $\mathrm{o}(0)$ & $5(5)$ & $32(36)$ & $53(59)$ \\
\hline $\begin{array}{l}\text { The amount of material presented on the topic of child } \\
\text { maltreatment at your medical school was sufficient }\end{array}$ & $29(32)$ & $22(24)$ & $23(26)$ & 10 (11) & $6(7)$ \\
\hline $\begin{array}{l}\text { Providing child maltreatment training in the workplace is } \\
\text { important }\end{array}$ & $3(3)$ & $2(2)$ & 8 (9) & $37(41)$ & $40(44)$ \\
\hline
\end{tabular}

The attitude of the participants to child maltreatment is given in Table 3. Most physicians strongly agreed/ agreed with the importance of detecting child maltreatment as well as the importance of their own roles in detecting and reporting cases of child physical abuse ( $98 \%$ and $99 \%$ respectively). Most ( $88 \%$ ) of the participants were confident in their ability to detect cases of child maltreatment if they encountered them. Moreover, $91 \%$, $93 \%$ and $94 \%$ of respondents, respectively, strongly agreed or agreed that documenting the signs and symptoms of abuse in the patient file, asking the child about injuries he/she had and reporting child abuse cases to a legal authority are important. Finally, more than half $(57 \%)$ strongly disagreed/disagreed that the amount of material presented on the topic of child abuse and neglect in their medical school was sufficient and 85\% strongly agreed/ agreed that providing training on child abuse and neglect in the work place was important.

According to the physicians, the main cause of underreporting was the lack of knowledge of the referral procedures $63(70 \%)$, followed by uncertainty about the diagnosis of child maltreatment $42(46.7 \%)$. Few physicians $16(17.8 \%)$ thought that lack of adequate history about the abuse case was a cause of underreporting.

Just over half $46(51 \%)$ of the physicians had suspected at least one case child maltreatment during their work (Table 4). Of these 46 physicians, $30(65 \%)$ had reported at least one case and $16(35 \%)$ had not reported any case of child maltreatment. In total, these physicians had experienced 249 suspected cases of child maltreatment, of which $148(59 \%)$ were confirmed and $89(36 \%)$ were reported. Of the $18 / 90$ (39\%) physicians who had suspected child maltreatment but reported that they took no action, $14(78 \%)$ reported that they did not do anything because of their lack of knowledge about referral procedures 12 $(67 \%)$ said they were uncertain about their diagnosis of child maltreatment, and $12(67 \%)$ were concerned about the possible harm the family might do to the child.
Physicians who reported child maltreatment were significantly more likely to have received formal training on child maltreatment $(P<0.001)$ and to be older $(P=0.006)$. Sex, years of experience, specialty and qualification were not significantly associated with physicians' reporting behaviour (Table 5).

More than half of the participants 50 (56\%) said that their workplace did not provide them with procedures to be followed in case of suspected child maltreatment and $24(27 \%)$ did not know if their workplace had such procedures. Two thirds of the physicians (60 (67\%)) were not satisfied with their knowledge on child maltreatment and 85 (94\%) wanted to improve their knowledge on the topic. More than half of the physicians (53 (59\%)) preferred informative booklets as a way to update their knowledge on child maltreatment, 28 (31\%) preferred continuing education courses, 28 (31\%) preferred self-study and 22 (24\%) suggested modifications of the medical curriculum.

\section{Discussion}

The results of our study show that the physicians' knowledge about the signs and social indicators of child maltreatment is unsatisfactory as only $11 \%$ correctly identified all the signs and $29 \%$ correctly answered all the questions on social indicators. Similar results have been reported in other parts of the world (9,14-16).

Burn marks was the most recognized sign $(96 \%$ of physicians knew this) which in agreement with results reported in Saudi Arabia (16). A large proportion (78\%) of our physicians wrongly identified bruises over bony prominences as a sign of child maltreatment, which is similar to dentists in Saudi Arabia (11), Jordan (9) and the United Arab Emirates (17). However, most such paediatric injuries (90\%) are in fact unintentional (18) and not a sign of child maltreatment (19).

Suspected cases of child maltreatment should be well documented and reported to the appropriate governmental agency whose role it is to investigate the 


\begin{tabular}{|c|c|}
\hline Question & Value \\
\hline \multicolumn{2}{|l|}{ Did you ever suspect that a child who came to you professionally had been maltreated? (No. (\%)) } \\
\hline Yes & $46(51)$ \\
\hline No & $44(49)$ \\
\hline \multicolumn{2}{|l|}{ How many child maltreatment cases have you ever suspected? } \\
\hline Range & $1-50$ \\
\hline Mean (SD) & $5.52(8.02)$ \\
\hline Median & 3.0 \\
\hline Total number of suspected cases & 249 \\
\hline \multicolumn{2}{|l|}{ How many child maltreatment cases have you ever diagnosed (confirmed)? } \\
\hline Range & $0.0-30.0$ \\
\hline Mean (SD) & $3.22(5.30)$ \\
\hline Median & 1.0 \\
\hline Total no. diagnosed (\% from suspected cases) & $148(59)$ \\
\hline \multicolumn{2}{|l|}{ Have you ever reported a child maltreatment case that you suspected? (No. (\%) ${ }^{a}$} \\
\hline No & $16(35)$ \\
\hline Yes & $30(65)$ \\
\hline \multicolumn{2}{|l|}{ How many cases have you reported? } \\
\hline Range & $0.0-13.0$ \\
\hline Mean (SD) & $1.93(2.98)$ \\
\hline Median & 1.0 \\
\hline Total no. reported (\% from suspected cases) $(n=249)$ & $89(36)$ \\
\hline \multicolumn{2}{|l|}{ What were your action(s) when you suspected a case of child maltreatment? (No. (\%) } \\
\hline Asked the child and/or parents & $31(67)$ \\
\hline Documented the sign/symptoms and suspicion in child's file & $31(67)$ \\
\hline Monitored the case during the following visits & $28(61)$ \\
\hline Checked the consistency of parents' and/or child's explanation with the clinical findings & $37(80)$ \\
\hline Did not do anything & $18(39)$ \\
\hline \multicolumn{2}{|l|}{ If you did not do anything, why was that? $(n=18)^{a}$} \\
\hline Fear of anger from family and parents & $6(33)$ \\
\hline Lack of knowledge about referral procedures & $14(78)$ \\
\hline Uncertainty about the diagnosis of the case as child maltreatment & $12(67)$ \\
\hline Lack of an adequate history about the child maltreatment case & $3(17)$ \\
\hline Possible harmful effect on the child from the family & $12(67)$ \\
\hline
\end{tabular}

\section{$S D=$ standard deviation.}

${ }^{a}$ The respondents who had never suspected a case of child maltreatment (44 physicians) were excluded.

${ }^{b}$ The respondents could select more than one answer.

case and help in child protection. Our study found that most of the physicians (88\%) thought that reporting to a legal authority was the first action that should be taken with a suspected case of child maltreatment which is higher than reported in dentists is Saudi Arabia (50\%) (7). More than half of our physicians (58\%) correctly chose the police as the legal authority to which the child maltreatment cases should be reported. In Turkey, physicians reported only to the social services (14). Disappointingly, $17 \%$ of our physicians did not know to which legal authority child maltreatment should be reported, which is in agreement a study among dentists (22\%) in the United Arab Emirates (17). Not being sure of the authority to which they should report child maltreatment could be because the law of children's rights in Egypt does not penalize the physicians for not reporting such cases (20).

Two thirds of our participants would report all cases to the authorities even if the abuse was only suspected, which is similar to a study in Turkey (76\%) (14). On the other hand, a different opinion was reported in a study of paediatricians in Saudi Arabia, $82 \%$ of whom considered that reporting should be mandatory only if serious injuries are suspected (21). This negative attitude may be due to the lack of clear legal and clinical guidelines in Arab countries on reporting suspected cases of child maltreatment.

Only $8 \%$ of our participants had received some formal training on child maltreatment, which is only slightly 


\begin{tabular}{|c|c|c|c|}
\hline \multirow[t]{3}{*}{ Characteristic } & \multicolumn{2}{|c|}{ Reported child maltreatment } & \multirow{3}{*}{$\begin{array}{c}\text { Test of significance } \\
\text { (P-value) }\end{array}$} \\
\hline & No $(n=60)$ & Yes $(n=30)$ & \\
\hline & No. & No. & \\
\hline \multicolumn{4}{|l|}{ Age (years) } \\
\hline$<30$ & 48 & 19 & \multirow[t]{2}{*}{$2.920 a(0.087)$} \\
\hline$\geq 30$ & 12 & 11 & \\
\hline Range & $25.0-32.0$ & $26.0-33.0$ & \multirow[t]{2}{*}{$2.806 \mathrm{~b}(0.006)$} \\
\hline Mean (SD) & $27.95(1.79)$ & $29.10(1.92)$ & \\
\hline \multicolumn{4}{|l|}{ Sex } \\
\hline Male & 33 & 13 & \multirow[t]{2}{*}{$1.089 a(0.297)$} \\
\hline Female & 27 & 17 & \\
\hline \multicolumn{4}{|l|}{ Years of experience } \\
\hline$\leq 5$ & 28 & 10 & \multirow[t]{2}{*}{$1.795 \mathrm{a}(0.432)$} \\
\hline $6-\leq 10$ & 27 & 18 & \\
\hline$>10$ & 5 & 2 & \multirow{3}{*}{$0.778 \mathrm{~b}(0.439)$} \\
\hline Range & $3.0-12.0$ & $4.0-10.0$ & \\
\hline Mean (SD) & $6.07(1.92)$ & $6.40(1.90)$ & \\
\hline \multicolumn{4}{|l|}{ Specialty } \\
\hline Paediatrics & 27 & 10 & \multirow[t]{4}{*}{$1.692 a(0.639)$} \\
\hline Orthopaedics & 10 & 8 & \\
\hline Emergency room & 11 & 6 & \\
\hline Forensics and toxicology & 12 & 6 & \\
\hline \multicolumn{4}{|c|}{ Highest/last scientific degree } \\
\hline Bachelor degree & 45 & 17 & \multirow[t]{2}{*}{$3.137 \mathrm{a}(0.077)$} \\
\hline Master degree & 15 & 13 & \\
\hline \multicolumn{4}{|c|}{$\begin{array}{l}\text { Have you ever received formal training on child } \\
\text { maltreatment? }\end{array}$} \\
\hline Yes & 0 & 7 & \multirow[t]{2}{*}{$15.181 a(<0.001)$} \\
\hline No & 60 & 23 & \\
\hline
\end{tabular}

$S D=$ standard deviation.

${ }^{a}$ Chi-squared test.

${ }^{b}$ Student $t$-test.

$P \leq 0.05$ was considered statistically significant.

lower than $11 \%$ reported in India (15). Our physicians had relatively limited knowledge of child maltreatment; only $41 \%$ had a knowledge score of $75 \%$ or more. A study in China also reported insufficient knowledge of health providers about child maltreatment (22). However, the knowledge score in our study is low compared with scores reported in a study in Saudi Arabia with a score of $84.2 \%$ (11). This may be due to the difference in specialty of the samples (the Saudi Arabian sample was dentists) and differences in scoring systems.

Older age and longer work experience were significantly associated with better knowledge. However, sex and specialty were not significantly associated with knowledge. A study in Turkey found similar results for age and work experience, but also found that female physicians had better knowledge than males (23).

Despite the limited knowledge, the attitudes expressed in the current study showed strong agreement with the important role of the physicians in the early diagnosis and reporting of child maltreatment and the value of receiving training on child maltreatment. This finding concurs with many studies in other countries (10,24-27).

Just over half of the physicians in our study had suspected at least one child maltreatment during their work. Higher proportions have been reported in Austria (28). Thus, almost half $(49 \%)$ said that they had never suspected child maltreatment. Not suspecting child maltreatment does not mean they had not met cases; perhaps they could not identify these cases because of their poor knowledge). One of the main causes of underreporting is lack of knowledge about signs of child abuse or how to suspect the case and this is confirmed by other results in our study. Of the 249 suspected cases reported by the physicians in our study, $59 \%$ were confirmed to be child abuse, but only about a third of the cases were reported by the physicians. Underreporting is still a global problem (29,30). Many reasons were mentioned as an explanation for this problem. The main reasons for underreporting given by our participants 
were lack of knowledge about referral procedures and unclear reporting steps. These reasons were also reported in studies in Saudi Arabia $(16,31)$. Improvement in reporting can only be expected when physicians are aware of their legal mandate and the proper procedures for reporting.

In agreement with as study in France (32), we found a significant association between reporting child maltreatment cases and physician's age and training. Most of our participants (82\%) said they had no clear procedures to follow or were unaware of the available services if they suspected a case of child maltreatment. Similar results were reported in a study in Turkey where $88 \%$ of the resident physicians and $78 \%$ of the experienced physicians considered that they had inadequate knowledge of the services available to deal with child maltreatment (33).

Although our study covered three hospitals, one of its limitations is that it was restricted to Alexandria, one of the urban governorates in Egypt. Larger-scale studies, including rural Egypt, where lower levels of knowledge and awareness are expected, would help give a more accurate picture of the situation in Egypt. Another limitation was the relatively low response rate which could be improved if interviewing method was used instead of self-completing the questionnaire.

In conclusion, physicians' knowledge about the signs and social indicators of child maltreatment was unsatisfactory. Most of participants wanted to improve their knowledge on child maltreatment. Physicians in Alexandria are in need of clinical training and education sessions to improve their ability to diagnosis and report cases of child maltreatment and clear procedures to assist them in doing so.

Funding: None.

Competing interests: None declared.

\section{Maltraitance des enfants : connaissances, attitudes et comportements des médecins en matière de signalement dans les hôpitaux universitaires, Alexandrie (Égypte)}

\section{Résumé}

Contexte : Le défaut de diagnostic et de signalement de la maltraitance des enfants constitue un problème important dans le monde.

Objectifs : La présente étude visait à évaluer les connaissances, l'attitude et la pratique des médecins des hôpitaux universitaires d'Alexandrie en matière de diagnostic et de signalement des cas de maltraitance d'enfants.

Méthodes: Une étude transversale descriptive a été menée dans trois hôpitaux. Tous les médecins travaillant régulièrement dans des services des urgences ont été invités à remplir un questionnaire auto-administré. Les données recueillies incluaient les caractéristiques sociodémographiques, les connaissances et la formation officielle concernant la maltraitance d'enfants, l'attitude face à cette dernière, et l'expérience des cas de maltraitance d'enfants ainsi que le comportement en matière de signalement.

Résultats : Au total, 90 médecins ont été inclus dans l'étude. Seuls 11 \% d'entre eux ont correctement identifié tous les signes de maltraitance d'enfants et $29 \%$ ont répondu correctement à toutes les questions sur les indicateurs sociaux de la maltraitance. Seulement $41 \%$ des participants avaient un bon score de connaissances sur la maltraitance des enfants $(\geq 75 \%)$. Une expérience professionnelle plus longue $(p=0,019)$ et un âge plus avancé $(p=0,039)$ étaient associés à une meilleure connaissance. Sur les 249 cas suspects de maltraitance d'enfants que les médecins ont déclaré avoir examinés, seuls $36 \%$ avaient fait l'objet d'un signalement. La formation formelle dans le domaine de la maltraitance des enfants $(p<0,001)$ et un âge plus avancé $(p=0,006)$ étaient associés au comportement des médecins en matière de signalement. Plus de la moitié des participants (56\%) estimaient que leur lieu de travail ne mettait pas à leur disposition des procédures à suivre en cas de suspicion de mauvais traitements envers les enfants.

Conclusion: Les médecins n'avaient pas une connaissance suffisante des signes et des indicateurs sociaux de la maltraitance des enfants. Une formation et un enseignement cliniques sont nécessaires pour améliorer leurs capacités de diagnostic et de signalement des cas de maltraitance d'enfants.

$$
\begin{aligned}
& \text { إساءة معاملة الطفل: معلومات الأطباء ومو اقفهم وسلو كهم في الإبلاغ بالمستشفيات التعليمية، الإسكندرية، مصر }
\end{aligned}
$$

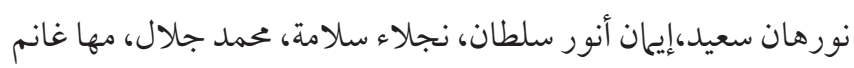

$$
\begin{aligned}
& \text { الخلاصة: } \\
& \text { الخلفية: يُعتبر عدم تشخيص حالات إساءة معاملة الأطفال والإبلاغ عنها من المشكلات المهمة في جميع أنحاء العالم. }
\end{aligned}
$$

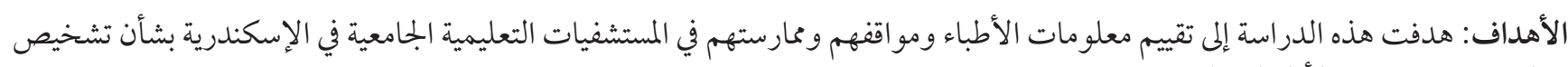

$$
\begin{aligned}
& \text { حالات إساءة معاملة الأطفال والإبلاغ عنها. }
\end{aligned}
$$




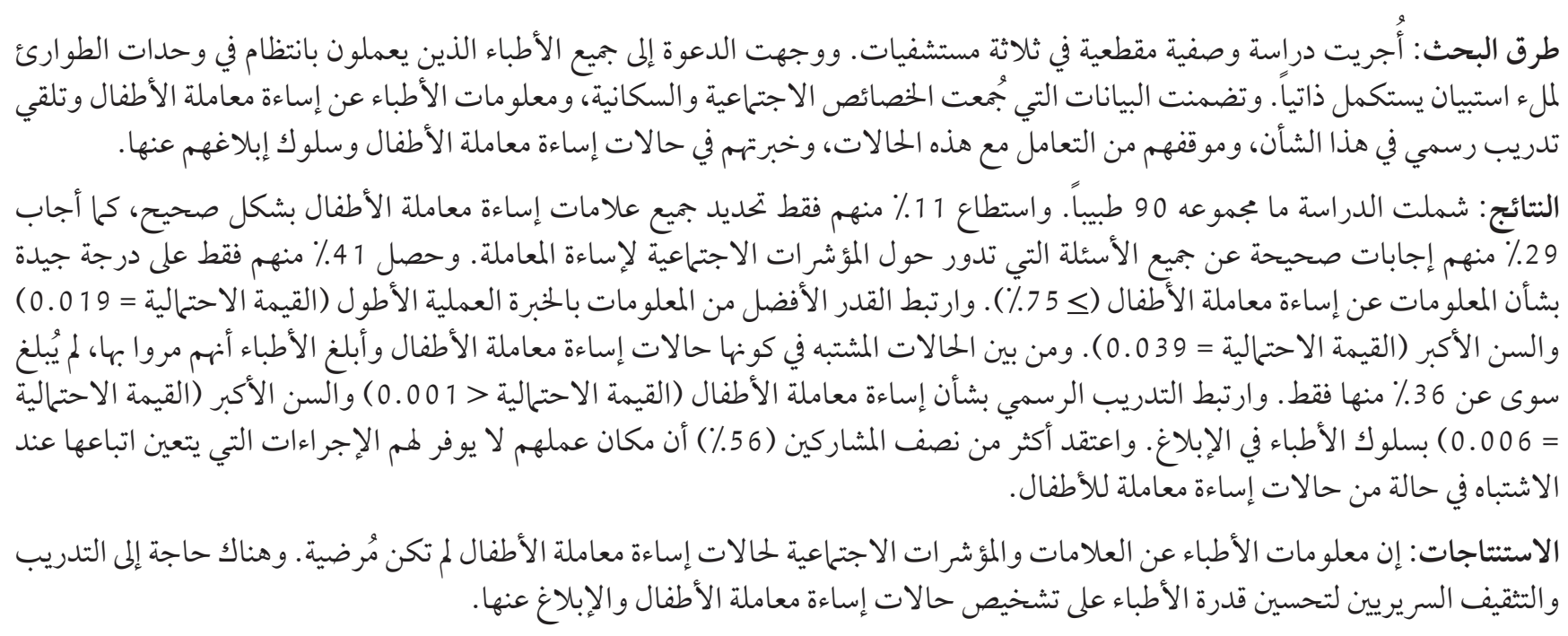

\section{References}

1. Diaz A, Petersen AC. Institute of medicine report: new directions in child abuse and neglect research. JAMA Pediatr. 2014;168(2):101-2. https://doi.org/10.1001/jamapediatrics.2013.4560

2. Violence against children. Child maltreatment. Geneva: World Health Organization; 2016 (https://www.who.int/health-topics/ violence-against-children\#tab=tab_1, accessed 22 September 2020).

3. Kunen S, Hume P, Perret JN, Mandry CV, Patterson TR. Under diagnosis of child abuse in emergency departments. Acad Emerg Med. 2003;10(5):546. https://doi.org/10.1197/aemj.10.5.423

4. World report on violence and health. Geneva: World Health Organization; 2002. (https://apps.who.int/iris/bitstream/handle/10665/42495/9241545615_eng.pdf?sequence=1, accessed 9 September 2020).

5. $\quad$ Levi BH, Crowell K. Child abuse experts disagree about the threshold for mandated reporting. Clin Pediatr. 2011;50(4):321-9. https://doi.org/10.1177/0009922810389170

6. Fraser JA, Mathews B, Walsh K, Chen L, Dunne M. Factors influencing child abuse and neglect recognition and reporting by nurses: A multivariate analysis. Int J Nurs Stud. 2010; 47(2):146-53. https://doi.org/10.1016/j.ijnurstu.2009.05.015

7. Antai D, Braithwaite P, Clerk G. Social determinants of child abuse: evidence of factors associated with maternal abuse from the Egypt demographic and health survey. J Inj Violence Res. 2016;8(1): 25-34. https://doi.org/10.5249/jivr.v8i1.630

8. Law No. 126 of 2008 for the Child Code [In Arabic]. Cairo: Government of Egypt; 2008 (http://www.egypt.gov.eg/arabic/laws/, accessed 22 September 2020).

9. Mogaddam M, Kamal I, Merdad L, Alamoudi N. Knowledge, attitudes, and behaviors of dentists regarding child physical abuse in Jeddah, Saudi Arabia. Child Abuse Negl. 2016;54(1):43-56. https://doi.org/10.1016/j.chiabu.2016.02.004

10. Pinto L, Lein A, Mahoque R, Wright DW, Sasser SM, Staton CA. A cross-sectional exploratory study of knowledge, attitudes, and practices of emergency health care providers in the assessment of child maltreatment in Maputo, Mozambique. BMC Emerg Med. 2018;18(1):11. https://doi.org/10.1186/s12873-018-0162-9

11. Al-Dabaan R, Newton JT, Asimakopoulou K. Knowledge, attitudes, and experience of dentists living in Saudi Arabia toward child abuse and neglect. Saudi Dent J. 2014;26(3):79-87. https://doi.org/10.1016/j.sdentj.2014.03.008

12. SPSS for Windows, version 20.0. Armonk, NY: IBM Corporation; 2012.

13. Kirkpatrick LA, Feeney BC. A simple guide to IBM-SPSS statistics for version 20.o. Bemont, CA: Wadsworth, Cengage Learning; 2013.

14. Demirçin S, Tütüncüler A, Aslan F, Güney SV, Atılgan M Gülkesen H. The knowledge level and opinions of physicians about the medical and legal procedures related to physical child abuse. Balkan Med J. 2017;34(2):140-6. https://doi.org/10.4274/balkanmedj.2015.1195

15. Deshpande A, Macwan C, Poonacha KS, Bargale S, Dhillon S, Porwal P. Knowledge and attitude in regards to physical child abuse amongst medical and dental residents of central Gujarat: A cross-sectional survey. J Indian Soc Pedod Prev Dent. 2015;33(3):177. https://doi.org/10.4103/0970-4388.160344

16. Alsaleem SA, Alsaleem MA, Asiri AM, Alkhidhran SS, Alqahtani WS, Alzahrani MS, et al. Knowledge and attitude regarding child abuse among primary health care physician in Abha, Saudi Arabia, 2018. J Family Med Prim Care. 2019;8(2):706. https://doi. org/10.4103/jfmpc.jfmpc_442_18

17. Sminkey L. World report on child injury prevention. Inj Prev. 2008;14(1):69. https://doi.org/10.1136/ip.2007.018143

18. Hashim, R, Al-Ani, A. Child physical abuse: assessment of dental students' attitudes and knowledge in United Arab Emirates. Eur Arch Paediatr Dent. 2013;14(5):301-5. https://doi.org/10.1007/s40368-013-0063-2 
19. Ramos-Gomez F, Rothman D, Blain S. Knowledge and attitudes among California dental care providers regarding child abuse and neglect. J Am Dent Assoc. 1998:129(3):340-8. https://doi.org/10.14219/jada.archive.1998.0208

20. The National Council for Childhood and Motherhood. Law No. 12 of 1996 promulgating the child law amended by law no. 126 of 2008. Cairo: Government of Egypt; 2008 (http://citizenshiprightsafrica.org/wp-content/uploads/2019/o1/Egypt-Child-Law-1996amended-2008-EN.pdf, accessed 9 September 2020).

21. Habib HS. Pediatrician knowledge, perception, and experience on child abuse and neglect in Saudi Arabia. Ann Saudi Med. 2012;32(3):236-42. https://doi.org/10.5144/0256-4947.2012.236

22. Li X, Yue Q, Wang S, Wang H, Jiang J, Gong L, et al. Knowledge, attitudes, and behaviors of healthcare professionals regarding child maltreatment in China. Child Care Health Dev. 2017;43(6):869-75. https://doi.org/10.1111/cch.12503

23. Kara Ö, Çalışkan D, Suskan E. Comparison of the levels of knowledge and approaches in relation with child abuse and neglect in residents of pediatrics, pediatricians and practitioners working in the province of Ankara. Türk Pediatri Arş. 2014;49(1):57. https:// doi.org/10.5152/tpa.2014.984

24. Andrade EM, Nakamura E, de Paula CS, do Nascimento R, Bordin IA, Martin D. A visão dos profissionais de saúde em relação à violência doméstica contra crianças e adolescentes: um estudo qualitative [The view of health professionals in relation to domestic violence against children and adolescents: a qualitative study]. Saúde e Sociedade. 2011;20(1):147-55.

25. Tansley G, Schuurman N, Amram O, Yanchar N. Spatial access to emergency services in low-and middle-income countries: a GIS-based analysis. PLoS One. 2015;10(11):e0141113. https://doi.org/10.1371/journal.pone.0141113

26. Laud A, Gizani S, Maragkou S, Welbury R, Papagiannoulis L. Child protection training, experience, and personal views of dentists in the prefecture of Attica, Greece. Int J Paediatr Dent. 2013;23(1):64-71. https://doi.org/10.1111/j.1365-263X.2012.01225.X

27. Harris CM, Welbury R, Cairns AM. The Scottish dental practitioner's role in managing child abuse and neglect. Br Dent J. 2013;214(9):E24. https://doi.org/10.1038/sj.bdj.2013.435

28. Kraus C, Jandl-Jager E. Awareness and knowledge of child abuse amongst physicians - a descriptive study by a sample of rural Austria. Wien Klin Wochenschr. 2011;123(11-12):340-9. https://doi.org/10.1007/s00508-011-1579-2

29. AlMadani O, Bamousa M, Alsaif D, Kharoshah MA, Alsowayigha A. Child physical and sexual abuse in Dammam, Saudi Arabia: a descriptive case-series analysis study. Egypt J Forensic Sci. 2012;2:33-7. https://doi.org/10.1016/j.ejfs.2012.01.001

30. Eads K. Breaking silence: underreported child abuse in the healthcare setting. Online J Health Ethics. 2013;9(1):1. http://dx.doi. org/10.18785/ojhe. 0901.01.

31. Elarousy W, Abed S. Barriers that inhibit reporting suspected cases of child abuse and neglect among nurses in a public hospital, Jeddah, Saudi Arabia. East Mediterr Health J. 2019;25(6):413-21 https://doi.org/10.26719/emhj.18.055

32. Regnaut O, Jeu-Steenhouwer M, Manaouil C, Gignon M. Risk factors for child abuse: levels of knowledge and difficulties in family medicine. A mixed method study. BMC Res Notes. 2015;8:620. https://doi.org/10.1186/s13104-015-1607-9

33. Gül H, Yürümez E, Yaylalı FH, Gül A. The perceptions of pediatricians regarding their self-efficacy in child neglect and abuse. Turk J Pediatr. 2015;57(5):475-81. 